\title{
Maksimum Güç Noktası İzleyici Algoritmalarının Verim, Salınım Miktarı ve Yakınsama Süresi Açısından Karşılaştırılması
}

\author{
Ufuk Badak $^{1 *}$, Ali Bekir Y1ldız

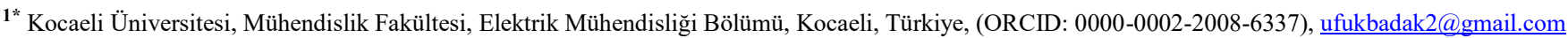 \\ ${ }^{2}$ Kocaeli Üniversitesi, Mühendislik Fakültesi, Elektrik Mühendisliği Bölümü, Kocaeli, Türkiye (ORCID: 0000-0003-4043-7859), abyildiz@kocaeli.edu.tr
}

(İlk Geliş Tarihi 7 Kasım 2020 ve Kabul Tarihi 24 Ocak 2021)

(DOI: 10.31590/ejosat.822975)

ATIF/REFERENCE: Badak, U. \& Yıldız, A. B. (2021). Maksimum Güç Noktası İzleyici Algoritmalarının Verim, Salınım Miktarı ve Yakınsama Süresi Açısından Karşılaştıılması. Avrupa Bilim ve Teknoloji Dergisi, (21), 463-472.

\section{Öz}

Yenilenebilir enerji kaynaklarından daha verimli sonuçlar elde etmek için, Maksimum Güç Noktası İzleyicisi (MGNİ) algoritmaları güç elektroniği devreleri ile birlikte kullanılmaktadır. Bu çalışmada, Değiştir ve Gözlemle algoritması, Artan İletkenlik algoritması ve Empedans Uyumluluğu algoritmasının bilgisayar ortamında benzetimi yapılmış ve iki farklı çalışma durumunda simülasyonları gerçekleştirilmiştir. Maksimum gücü $213.15 \mathrm{~W}$ olan panellerden, iki adet seri ve iki adet paralel şekilde kullanılarak, DA - DA yükseltici dönüştürücü aracılı̆̆ıla, sözü edilen algoritmalar kullanılarak yaklaşık $\% 90-\% 96,5$ arası verim ile panel güçlerinin yüke aktarımı sağlanmıştır. Her bir algoritma, simülasyon sonucunda elde edilen verim, salınım miktarı ve yakınsama süreleri açısından karşılaştırılmıştır.

Anahtar Kelimeler: Değiş̧ir ve Gözlemle algoritması, Artan İletkenlik algoritması, Empedans Uyumluluğu algoritması, Verim, Salınım miktarı, Yakınsama süresi.

\section{Comparison of Maximum Power Point Tracker Algorithms in Terms of Efficiency, Amount of Oscillation and Convergence Time}

\begin{abstract}
Maximum Power Point Tracking (MPPT) algorithms are used in conjunction with power electronics circuits to obtain more efficient results from renewable energy sources. In this study, Perturb and Observe algorithm, Incremental Conductance algorithm and Impedance Compatibility algorithm have been simulated in the computer environment and simulated in two different operating conditions. From the panels with a maximum power of $213.15 \mathrm{~W}$, using two serial and two parallel panels, the panel powers were transferred to the load with an efficiency of approximately $90 \%-96.5 \%$ using the aforementioned algorithms via DA-DA converter. Each algorithm is compared in terms of efficiency, oscillation amount and convergence times obtained as a result of the simulation.
\end{abstract}

Keywords: Perturb and Observe Algorithm, Incremental Conductance Algorithm, Impedance Compatibility Algorithm, Efficiency, Oscillation Amount, Convergence Time. 


\section{Giriş}

Dünya genelinde fosil yakıt kaynaklarının azalması, kullanılan fosil yakıtların küresel 1sınmaya sebep olması ve çevreye verdiği zararlardan ötürü çevresel kaygıların artmasından dolayı, yenilenebilir enerji kaynaklarına olan talep günümüzde git gide artmaktadır [1]. Enerji sektöründe fosil yakıtara bağımlılığı azaltmada büyük bir paya sahip olan güneş enerjisi yenilenebilir enerji kaynakları arasında en önemli enerji kaynaklarından biri olarak kabul edilmektedir [2]. Yenilenebilir enerji kaynaklarından olan güneş enerjisi sınırsız olması, çevre ve gürültü kirliliğine yol açmaması, yakıt gereksinimi olmaması, işletme maliyetinin düşük olması ve devlet tarafindan desteklenmesi gibi avantajlara sahipken, ilk yatırım maliyetinin yüksek olması ve enerji dönüşüm verimliliğinin düşük olması gibi dezavantajlara sahiptir [3-5].

Güneş panelleri, güneş 1şı̆̆ını doğrudan elektrik enerjisine dönüştürmektedir. Elde edilen bu elektrik enerjisi güneşin 1şınım miktarına, ışınım açısına, ortam sıcaklığına, gölgelenmelere ve panel yüzey temizliğine göre değişebilmektedir [6]. Değişken olan bu parametreler ve güneş panellerinin enerji dönüşüm verimliliğinin düşük olması nedeniyle, güneş panellerinden üretilen gücün maksimum seviyede tutulması amaçlanmaktadır [7]. Bu doğrultuda literatürde birden çok Maksimum Güç Noktas1 İzleyici teknikleri geliştirilmiştir [8-10].

Güneş paneli uygulamalarında, sistemi maksimum güç noktasında çalıştırmak ve yüksek verimlilik elde etmek istenmektedir [11]. Bu doğrultuda, güneş panellerinde üretilen gücü, talep edilen çıkış gücüne yüksek verimlilikle transfer edebilmek için MGNİ birimi ile birlikte DA -DA dönüştürücüler kullanılmaktadır [12]. MGNI birimi ile DA -DA dönüştürücünün doluluk oranı kontrol edilerek, panel maksimum güç noktasında çalıştırılır [13-14].

$\mathrm{Bu}$ çalışmada maksimum güç noktasının yerini tespit etmek için kullanılan Değiştir ve Gözlemle algoritması, Artan İletkenlik algoritması ve Empedans Uyumluluğu algoritması ele alınmıştır. $\mathrm{Bu}$ algoritmaların Matlab/Simulink ortamında benzetimi yapılmış, yapılan benzetimde iki farklı çalışma durumu ele alınmış ve her bir algoritmanın bu kriterlere göre simülasyonu gerçekleştirilmiştir. Çalışmanın temel katkısı, bu algoritmaların verim, maksimum güç noktasındaki salınım miktarı ve yakınsama süreleri açısından karşılaştırılmasıdır.

\section{Maksimum Güç Noktası İzleyici Algoritmalarının Tanımlanması}

Güneş panellerinden maksimum gücün elde edildiği noktaya maksimum güç noktası denir. Maksimum güç noktasının tespit edilebilmesi için maksimum güç takip sistemleri ve ekipmanları kullanılır. Maksimum güç noktası izleyici tekniği, belirli bir güneş 1şınımı altında güneş panelinden $\mathrm{P}_{\mathrm{MPP}}$ maksimum güç çıkışı elde etmek için, $\mathrm{V}_{\text {MPP }}$ gerilim değeri, $\mathrm{I}_{\mathrm{MPP}}$ akım değerlerinin bulunması ilkesine dayanır (Şekil 1) [15]. Güneş panellerinde maksimum güç noktası, güneş 1şınım miktarı, ışınım açısı, panel sıcaklığı, gölgelenme ve panel yüzey temizliği gibi değişken olan çevresel etkenlerle değişebilmektedir. Değişken olan bu parametrelerden dolayı güneş panellerinden sürekli olarak maksimum güç elde edilememektedir. Panellerden sürekli olarak maksimum güç elde edebilmek için farklı maksimum güç noktası izleyici teknikleri geliştirilmiştir [16]. Şekil 1'de, güneş panellerinde maksimum güç noktası ve bu noktanın panel akım ve gerilimiyle ilişkisi gösterilmiştir [17].

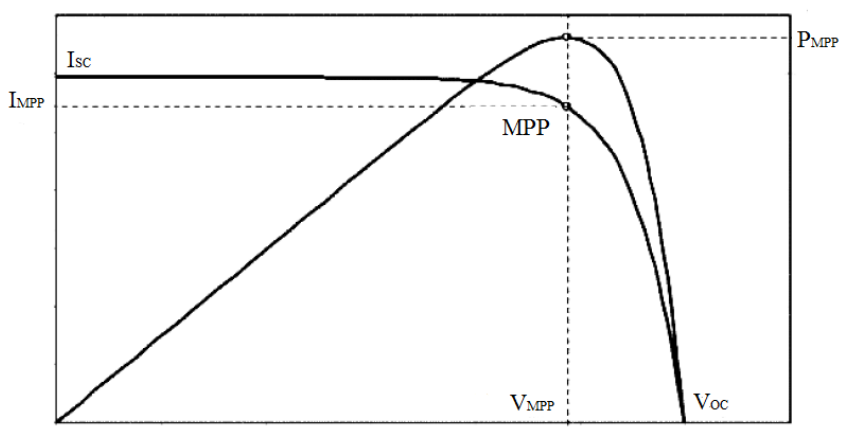

Şekil 1. PV panel I-V ve P-V karakteristiklerine göre maksimum güç noktası

Şekil 1'deki karakteristiğe göre, her çalışma koşulu için yalnızca bir maksimum güç noktası mevcuttur. Maksimum güç noktasında PV karakteristiğine göre eğim sıfırdır. Yani $d P / d V=0$ olmaktadır. Şekil 1'e göre maksimum güç noktası denklem 1'de ki gibi ifade edilir.

$P_{M P P}=I_{M P P} V_{M P P}$

Maksimum güç noktasının yerini tespit edebilmek için geliştirilmiş bir çok teknik mevcuttur. $\mathrm{Bu}$ çalışmada bu tekniklerden, Değiştir ve Gözlemle algoritması, Artan İletkenlik algoritması ve Empedans Uyumluluğu algoritması ele alınmıştır. Bu bölümde, belirlenen algoritmalar tanıtılmış, akış diyagramları gösterilmiş ve işleyişi açıklanmıştır.

\subsection{Değiştir ve Gözlemle Algoritması}

Değiştir ve gözlemle algoritmasında, güneş panelinin karakteristik P-V eğrisinden ve güç-gerilim yapısından faydalanılır. $\mathrm{Bu}$ algoritma, sistemde sürekli olarak güneş panelinin gücünü takip eder [18]. Maksimum güç noktasına ulaşmak için, örneklenmiş olan güneş panelinin geriliminde artım veya azaltım yapılır. Yapılan gerilim artımı veya azaltımından sonra, güç değişimi hesaplanır $(\Delta P) . \Delta P$ değeri pozitifse, çalışma gerilimi tekrar artırılarak, güneş paneli çalışma noktası maksimum güç noktasına yaklaştırılır. Böylece gerilimde küçük hatalar oluşturularak panel gücünde meydana gelen hatanın işareti izlenir [19].

$\mathrm{Bu}$ algoritmada, maksimum güç noktasının sağındayken gerilim değeri artırıldığında güç değeri artacak, gerilim değeri azaltıldığında ise güç azalacaktır. Eğer maksimum güç noktasının sol tarafında gerilim değeri arttırıldığında güç azalacak, gerilim değeri azaltığında güç artacaktır. $\mathrm{Bu}$ doğrultuda gerilim değerindeki değişim ve buna bağlı olarak güçteki değişime göre bir sonraki adımdaki gerilim değişimi belirlenir. Maksimum güç noktasına ulaşabilmek için gerilim değeri değişim kararı Tablo 1 'de verilmiştir. $\mathrm{Bu}$ algoritmanın işleyişini gösteren akış diyagramı ise Şekil 2'de gösterilmiştir. 
Tablo 1. Gerilim değeri değişimi karar tablosu

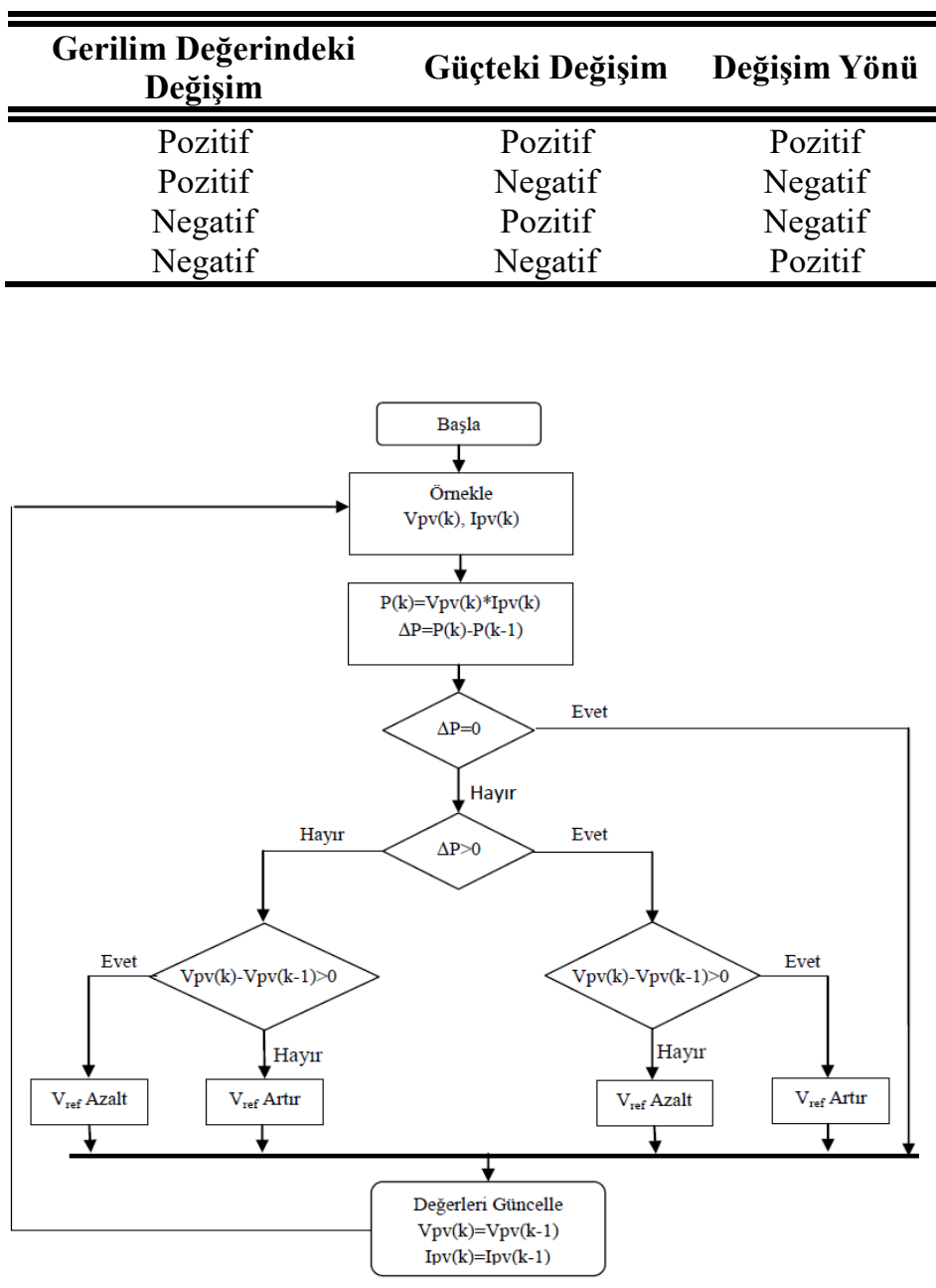

Şekil 2. Değiştir ve gözlemle algoritması akış diyagramı

\subsection{Artan İletkenlik Algoritması}

Artan iletkenlik algoritması, güneş panelinin çıkış gücünün eğiminin sıfir olduğu yeri maksimum güç noktası, eğimin pozitif olduğu yeri maksimum güç noktasının solu, eğimin negatif olduğu yeri ise maksimum güç noktasının sağı olarak belirler. Şekil 3'de Artan iletkenlik algoritmasının çalışma eğrisi gösterilmiştir. Bu eğriden yararlanılarak denklem 2, denklem 3 ve denklem 4'deki eşitlikler elde edilir. Şekil 4'de Artan iletkenlik algoritmasına dair akış diyagramı verilmiştir.

$\frac{d P}{d V}=0 \rightarrow$ Maksimum Güç Noktası

$\frac{d P}{d V}>0 \rightarrow$ Maksimum Güç Noktasının Solu

$\frac{d P}{d V}<0 \rightarrow$ Maksimum Güç Noktasının Săg $l$

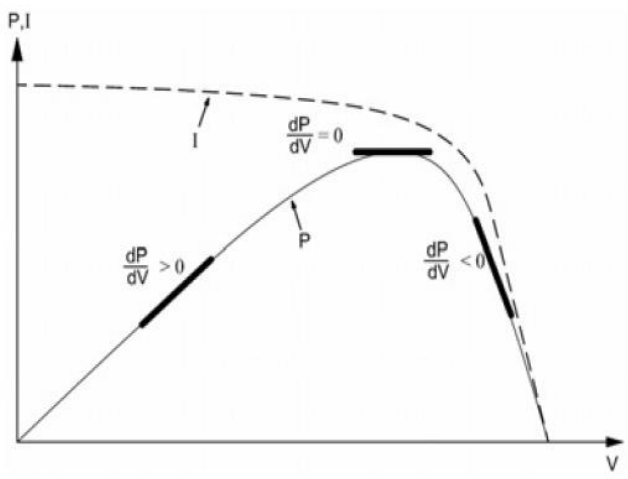

Şekil 3. Artan İletkenlik Algoritması Çalışma Ĕ̆risi

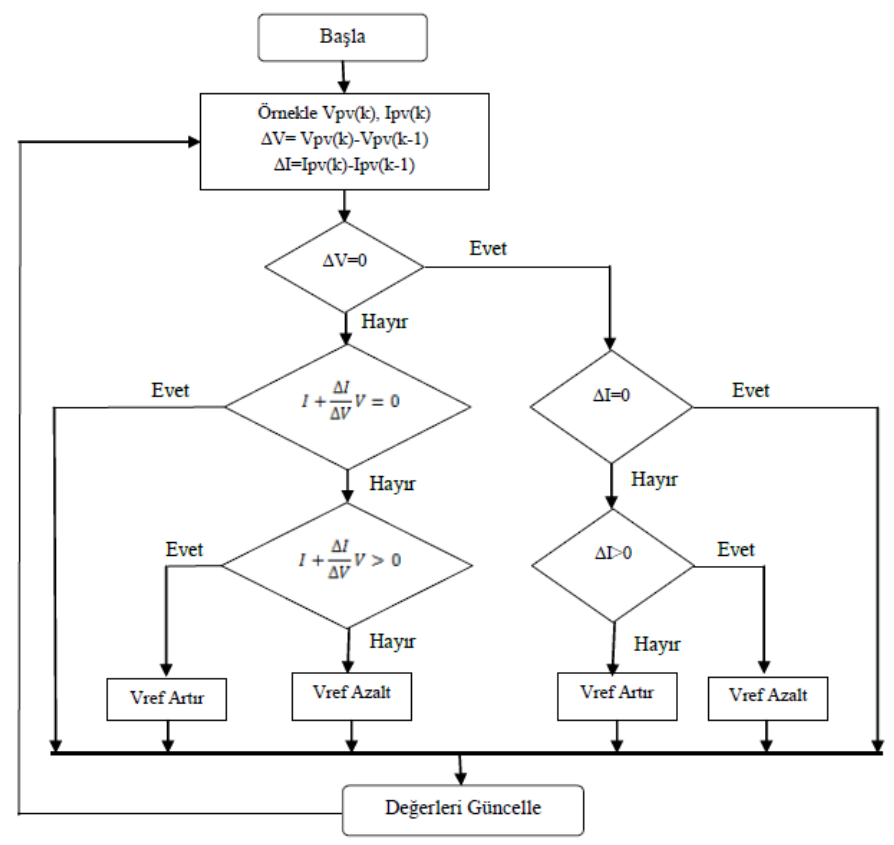

Şekil 4. Artan İletkenlik Algoritması Akış Diyagraması

\subsection{Empedans Uyumluluğu Algoritması}

Empedans uyumluluğu algoritması, elektriksel sistemlerdeki max. güç transferi teoremine dayanmaktadır. Bu teorem ile, güneş panelinden maksimum güç sağlayabilmek için, üretilen gücün yüke en yüksek verim ile aktarılması hedeflenmektedir. Güneş panelinin verimli bir güç kaynağı olarak kullanılabilmesi için panelin iç direnci ve yük empedanslarının eşit olması gerekir. Bu eşitliği sağlayabilmek için empedans uyumluluğu yöntemi kullanılır. Maksimum güç noktası izleme algoritmalarını kullanabilmek için, aracı bir sistem olarak DA-DA dönüştürücüler ve eviriciler kullanılmaktadır. Bu çalışmada, DA-DA yükselten dönüştürücü kullanılarak, yük ile panel arasında anahtarlamalı olarak nasıl empedansların eşitlendiği incelenmiştir.

Şekil 5 incelendiğinde, $\mathrm{R}_{\mathrm{L}}^{\prime}$ 'nin dönüştürücünün girişine yani panelin çıkışına indirgenmiş yük direnci olduğu görülmektedir. Yükün indirgenmiş halinin değerinin bağlı olduğu parametreler, denklem 5 'te verilmiştir. 


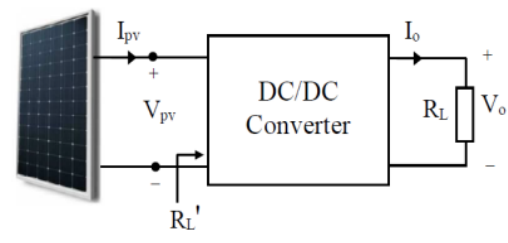

Şekil 5. DA-DA Dönüştürücünün girişine Indirgenmiş Yük ve Thevenin Eşdeğer Devresi

$$
V_{O}=\frac{1}{1-D} \cdot V_{P V}
$$

Denklem 5'de $V_{O}$ yük gerilimi, $V_{P V}$ panel gerilimi ve $D$ kontrol sinyalinin doluluk oranıdır. Bu denklemde $\frac{1}{1-D}$ yerine $N$ sabiti kullanılırsa, $\quad V_{o}=N \cdot V_{p v}$ olacak şekilde yükseltici dönüştürücünün çıkış gerilimi ifade edilir. Denklem 6'da $P_{O}$ çıkış gücü, $P_{P V}$ panel gücüdür. $\mathrm{Bu}$ güçler birbirine eşit olduğunda maksimum güç transferi gerçekleştirilmiş olur.

$$
P_{O}=P_{P V}=\frac{V_{P V}^{2}}{R_{P V}}=\frac{V_{O}^{2}}{R_{L}}
$$

Çıkış gerilimin yerine $V_{o}=N \cdot V_{p v}$ eşitliği kullanılırsa denklem 7 elde edilir:

$$
\frac{V_{P V}^{2}}{R_{P V}}=\frac{N^{2} \cdot V_{O}^{2}}{R_{L}}
$$

Buna göre,

$$
\frac{1}{R_{P V}}=\frac{N^{2}}{R_{L}}
$$

Denklem 8'de, N yerine Darbe Genişlik Modülasyonu'nun doluluk oranını yazılırsa, denklem 9 elde edilir.

$$
D=1-\sqrt{\frac{R_{p v}}{R_{L}}}
$$

Denklem 9'a göre, yük ve panelin iç direnci dikkate alınarak maksimum güç aktarımı için gerekli kontrol sinyali üretilir. Panel girişine indirgenmiş direncin doluluk oranı ile ilişkisi, denklem 10'da verilmiştir.

$$
R_{L}^{\prime}=\left(1-D^{2}\right) \cdot R_{L}
$$

Bulunan doluluk oranı sayesinde her bir çevrim süresinde girişe indirgenmiş direnç bulunur. $\mathrm{Bu}$ işlem her bir çevrim boyunca tekrarlandığında, eğer sistemde yük, ışınım ve sıcaklık değişimi varsa doluluk oranı tekrar hesaplanır ve girişe indirgenmiş direnç değeri güncellenir. Her bir çevrimde bu işlem yapılarak empedans uyumluluğu algoritmasının gerçeklenmesi sağlanır.

\section{MGNi Matlab/Simulink Benzetimi}

Tanımlanan algoritmaların Matlab/Simulink ortamında benzetiminin yapılabilmesi için Şekil 6'da verilen model tasarlanmıştır. Tasarlanan modele göre sistemin her bir çalışma durumu için verimi, sistemin maksimum güç noktasında yaptığ 1 salınım miktarı ve sistemin yakınsama süreleri elde edilmektedir. Verim, yük gücünün ideal güce oranıdır. Salınım miktarı, sistemin maksimum güç noktasında yaptığı dalgalanmanın tepeden tepeye değişim miktarıdır. Yakınsama süresi ise sistemin maksimum güç noktasına ulaşması için gerekli olan süredir.
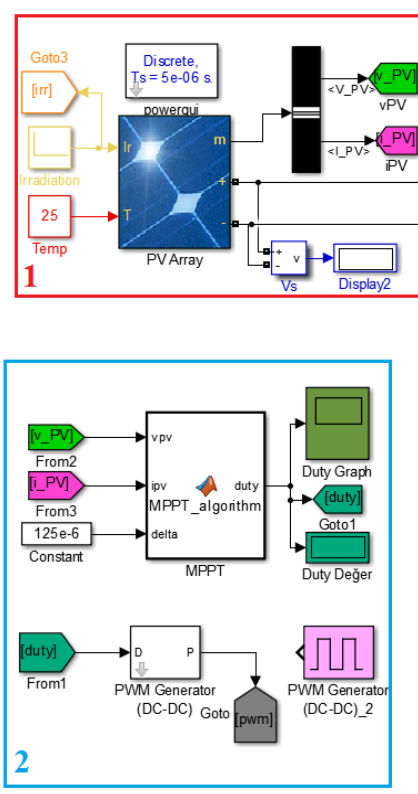
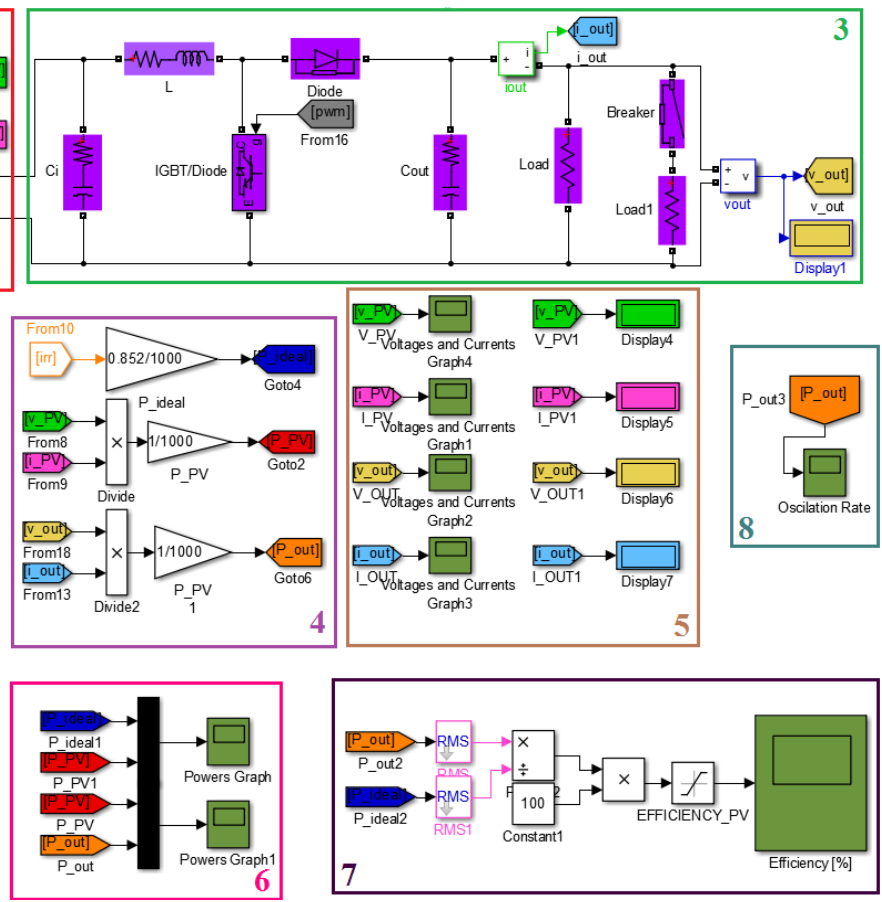

Şekil 6. Algoritmaların gerçeklenmesi için oluşturulan Matlab/Simulink modeli

(Burada; 1: Güneş paneli bloğu, 2:MGNí birimi bloğu, 3:DA -DA dönüştürücü bloğu, 4:Güç ölçüm bloğu, 5: Panele akım ve gerlim ile yük akım ve gerilim ölçüm bloğu, 6:İeal, panel ve yük güçleri klyaslama bloğu, 7:Verim değeri gözlem bloğu, 8:

Maksimum güç noktasındaki salınım gözlem bloğu.) 
Tasarlanan modelde bir numaralı blokta, 1şınım ve sıcaklık değerleri panele girdi olarak verilmiştir. İki numaralı blok sistemin MGNI birimidir. MGNI biriminde, maksimum güç noktasını tespit edecek fonksiyon bloğu mevcuttur. Burada bulunan fonksiyon bloğuna her bir algoritma için geçerli koşullar tanımlanarak, her biri için oluşturulan simülasyon modeli çalıştırılmaktadır. Fonksiyon bloğunun giriş parametreleri panel akımı ve panel gerilimi, çıkış parametresi ise doluluk oranıdır. Aynı zamanda burada elde edilen doluluk oranındaki değişim grafiksel olarak gözlemlenebilmektedir. Elde edilen doluluk oranı üç numaralı blokta bulunan yükselten DA-DA dönüştürücüde bulunan kontrol edilebilir anahtarlama elemanının tetikleme ucuna uygulanarak dönüştürücü kontrol edilir. Dört numaralı blokta, panel gücü ve yük güçleri elde edilmektedir. Bu amaçla, bir numaralı blokta ölçülen panel akım ve gerilimi ile panel gücü, üç numaralı blokta ölçülen yük akım ve gerilimi ile yük güçleri belirlenmektedir. Beş numaralı blokta, bir ve üç numralı bloklarda elde edilen panel akım ve gerilimleri ile yük akım ve gerilimleri grafiksel olarak çizdirilmiş ve sayısal değerleri anlık olarak gözlemlenmiştir. Altı numaralı blokta, dört numaralı blokta elde edilen panel ve yük güçleri, ideal güç ile kıyaslanmış ve grafiksel olarak çizdirilmiştir. Yedi numaralı blokta, yük gücü ideal güç ile oranlanmış ve verim elde edilmiştir. Elde edilen verim grafiksel olarak çizdirilmiştir. Sekiz numaralı blokta yük gücü grafiksel olarak çizdirilmiş ve sistemin maksimum güç noktasında yaptığı salınım miktarı ve yakınsama süreleri incelenmiştir. Tasarlanan modelde kullanılan güneş paneline ait elektriksel parametreler Tablo 2'de verilmiştir.

Sistemin çalışma koşulları, $\mathrm{t}=0$.sn ile $\mathrm{t}=2$.sn aralığında ışınım değeri $1000 \mathrm{~W} / \mathrm{m}^{2}$, dir. $\mathrm{t}=2$.sn ile $\mathrm{t}=4$.sn aralığında sistemin ışıma miktarında değişim olmadan sisteme paralel olarak $100 \Omega$ 'luk omik bir yük ilave edilmektedir (Çalışma koşulundaki değişim). $\mathrm{Bu}$ çalışma koşulları altında panel akım ve gerilimleri ile yük akım ve gerilimleri ölçülerek, panel gücü ve yük gücü ölçülmüş ve grafiksel olarak değişimleri elde edilmiştir. Elde edilen panel gücü ve yük gücü ideal güç ile kıyaslanarak, verim, salınım miktarı ve yakınsama süreleri her bir algoritma için belirlenmiştir.

Tablo 2. Kullanılan güneş panelinin elektriksel özellikleri

\begin{tabular}{cc}
\hline \hline Parametre & Değer \\
\hline \hline Panel modeli & 1Soltech 1STH-215-P \\
Kisa devre akımı $\left(I_{S C}\right)$ & $7.84 \mathrm{~A}$ \\
Açı devre gerilimi $\left(V_{O C}\right)$ & $36.3 \mathrm{~V}$ \\
Maksimum güçte akım $\left(I_{M P P}\right)$ & $7.35 \mathrm{~A}$ \\
Maksimum güçte gerilim $\left(V_{M P P}\right)$ & $29 \mathrm{~V}$ \\
Maksimum güç $\left(P_{M P P}\right)$ & $213.15 \mathrm{~W}$ \\
\hline
\end{tabular}

\subsection{Yükselten DA - DA Dönüștürücü}

Güneş panellerinden maksimum güç elde ederek yüke aktarılması için tasarlanan modelde (Şekil 6) yükselten dönüştürücü kullanılmıştır. Dönüştücü yapısında bulunan kontrol edilebilir anahtarlama elemanı, doluluk oranı ile kontrol edilmekte ve böylece yüke maksimum güç aktarılamaktadır. Şekil 7'de görüldüğü gibi yükselten dönüştürücü MGNİ birimi ile kontrol edilmekte ve bu sayede yüke maksimum güç aktarılmaktadır.

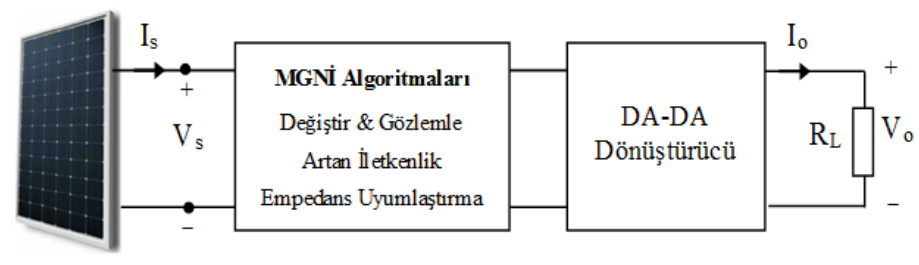

Şekil 7. Yükselten DA-DA Dönüştürücü ve MGNI Sistemi

Kullanılan modelde yükselten dönüştürücünün giriş gerilimi $\left(V_{S}\right)$ panelin çıkış gerilimiyken, dönüştürücünün çıkış gerilimi $\left(V_{O}\right)$ ise yük gerilimidir. Yülseten dönüştürücünün temel devre şeması ise aşağıda Şekil 8'de verilmiştir.

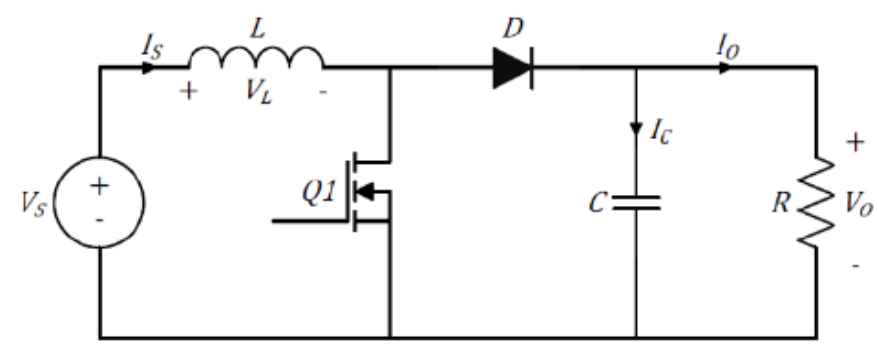

Şekil 8. Yükselten DA-DA dönüştürücü devresi

Dönüştürücüde bulunan elemanların değerleri aşağıda Tablo 3 'te verilmiştir.

Tablo 3. Yükselten DA-DA dönüş̧ürücü de kullanılan elemanların değerleri

\begin{tabular}{cc}
\hline \hline Eleman & Değer \\
\hline \hline $\mathrm{C} 1(\mu \mathrm{F})$ & 100 \\
$\mathrm{~L} 1(\mathrm{mH})$ & 2 \\
$\mathrm{C} 2(\mu \mathrm{F})$ & 100 \\
$\mathrm{R} 1(\Omega)$ & 100 \\
$\mathrm{R} 2(\Omega)$ & 100 \\
Frekans $($ Hertz $)$ & 7500 \\
\hline
\end{tabular}

\subsection{Maksimum Güç Noktası İzleyici Birimli Çalışma}

Tasarlanan modelde, Bölüm 2'de tanımlanan algoritmalara ait simülasyonlar gerçekleştirilmiştir. Sümülasyon sonucunda elde edilen ideal güç, panel gücü ve yük güçleri birbiri ile kıyaslanmış ve değişimleri grafiksel olarak çizdirilmiştir. Buna ek olarak, sistemi kontrol eden doluluk oranındaki değişim grafiksel olarak çizdirilmiştir. Burada elde edilen güçler ile birlikte yük ve panel güçleri oranlanarak her bir algoritma için verim elde edilmiştir. Bulunan yük güçlerine göre, her bir algoritma için maksimum güç noktasındaki salınım miktarı ve yakınsama süreleri hakkında bilgiler elde edilmiştir.

\subsubsection{Değiş̧tir ve Gözlemle Algoritması}

Tasarlanan model, Değiştir ve Gözlemle algoritması için çalıştırılmıştır. Elde edilen ideal güç, panel gücü ve yük güçleri belirlenmiştir. Şekil 9.a'da panel gücü ile ideal güç arasındaki ilişki, Şekil 9.b'de yük gücü ile ideal güç arasındaki ilişki verilmiştir. Şekil 10'da ise her bir çalışma koşulunda anlık olarak doluluk oranının değişimi verilmiştir. 


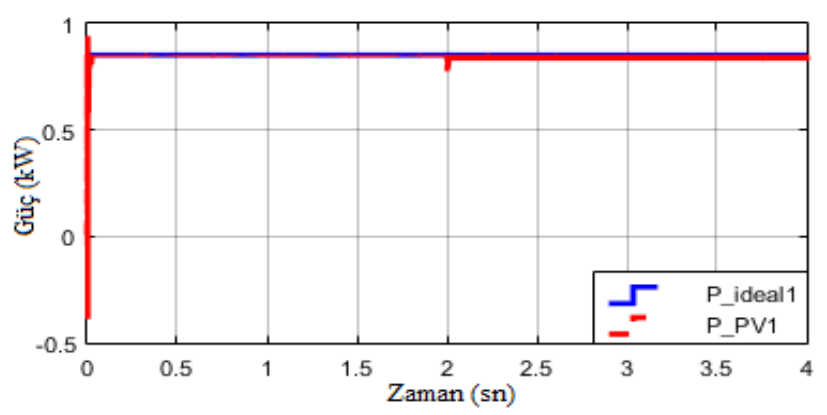

a) İdeal ve Panel güçleri

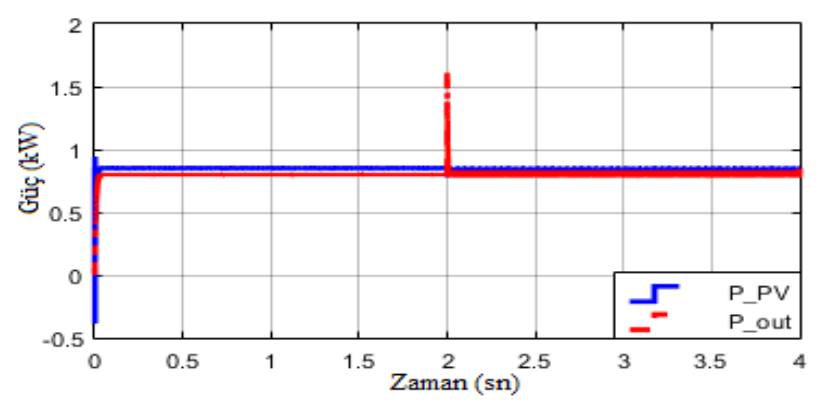

b) Panel ve Yük güçleri

Şekil 9. İdeal, Panel ve Yük güçleri

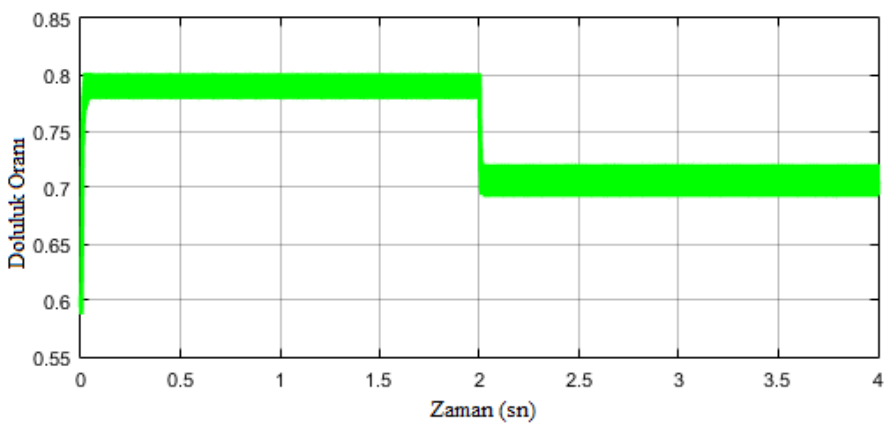

Şekil 10. Doluluk oraninda ki değiş̧im

\subsubsection{Artan Illetkenlik Algoritmast}

Tasarlanan model Artan İletkenlik algoritması için çalıştırılmıştır. Elde edilen ideal güç, panel gücü ve yük güçleri belirlenmiştir. Şekil 11.a'da panel gücü ile ideal güç arasındaki ilişki, Şekil 11.b'de yük gücü ile ideal güç arasındaki ilişki verilmiş̧ir. Şekil 12'de ise her bir çalışma koşulunda anlık olarak doluluk oranının değişimi verilmiştir.

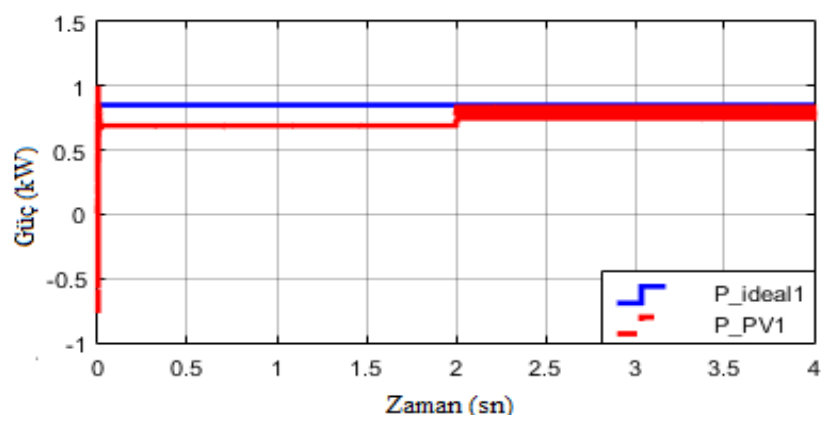

a) İdeal ve Panel güçleri

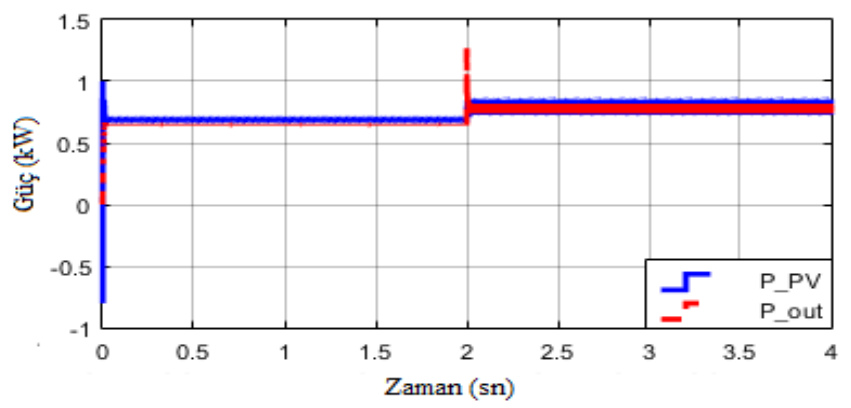

b) Panel ve Yük güçleri

Şekil 11. İdeal, Panel ve Yük güçleri

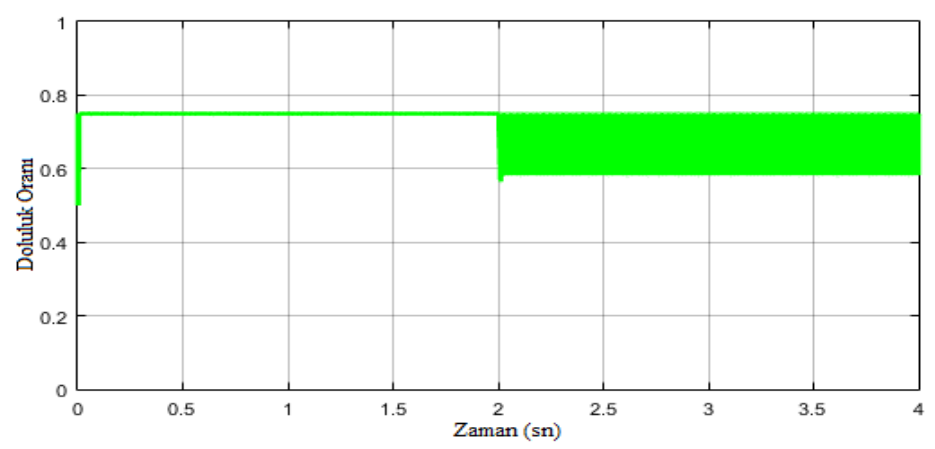

Şekil 12. Doluluk oranında ki değişim

\subsubsection{Empedans Uyumluluğu Algoritması}

Tasarlanan model Empedans Uyumluluğu algoritması için çalıştırılmıştır. Elde edilen ideal güç, panel gücü ve yük güçleri belirlenmiştir. Şekil 13.a'da panel gücü ile ideal güç arasındaki ilişki, Şekil 13.b'de yük gücü ile ideal güç arasındaki ilişki verilmiştir. Şekil 14'de ise her bir çalışma koşulunda anlık olarak doluluk oranının değişimi verilmiştir.

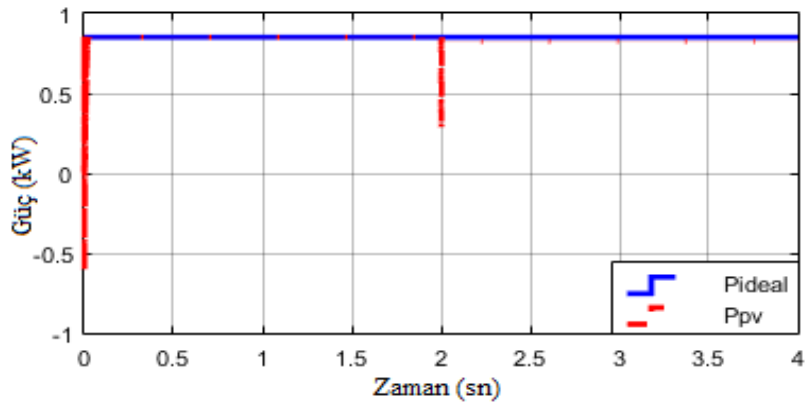

a) İdeal ve Panel güçleri

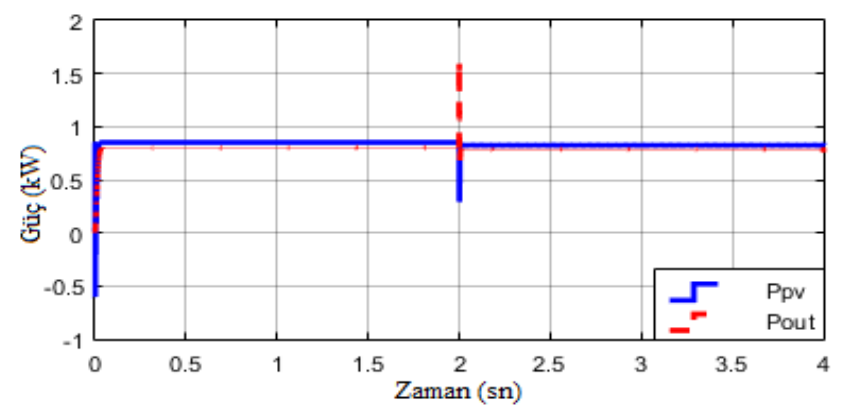

b) Panel ve Yük güçleri

Şekil 13. İdeal, Panel ve Yük güçleri 


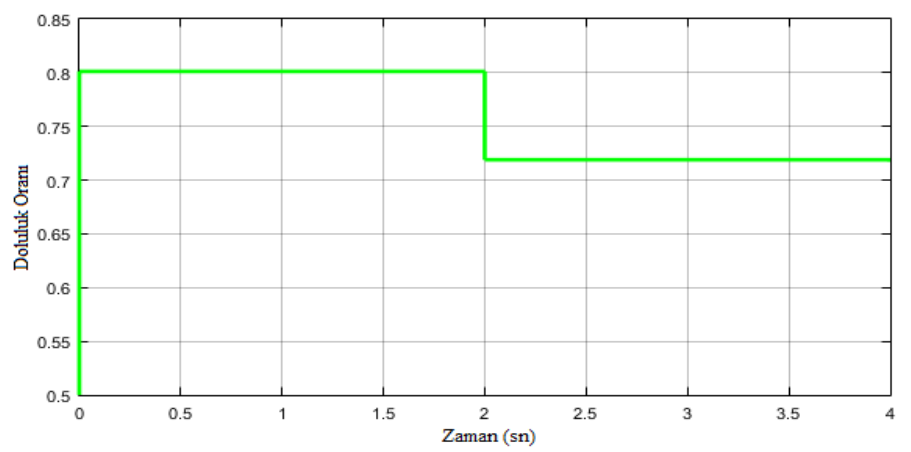

Şekil 14. Doluluk oranında ki değişim

\section{Matlab/Simulink Karşılaştırılması}

Bu bölümde, Bölüm 3.2'de elde edilen ideal güç, panel gücü ve yük güçleri için her bir çalışma koşulunda elde edilen verim, maksimum güç noktasındaki salınım miktarı ve yakınsama süreleri grafiksel olarak çizdirilmiş ve ortalama sayısal değerleri tablolar eşliğinde belirtilmiştir. Elde edilen sonuçlar aşağıda ilgili başlıklar alında ele alınmıştır.

\subsection{Verim}

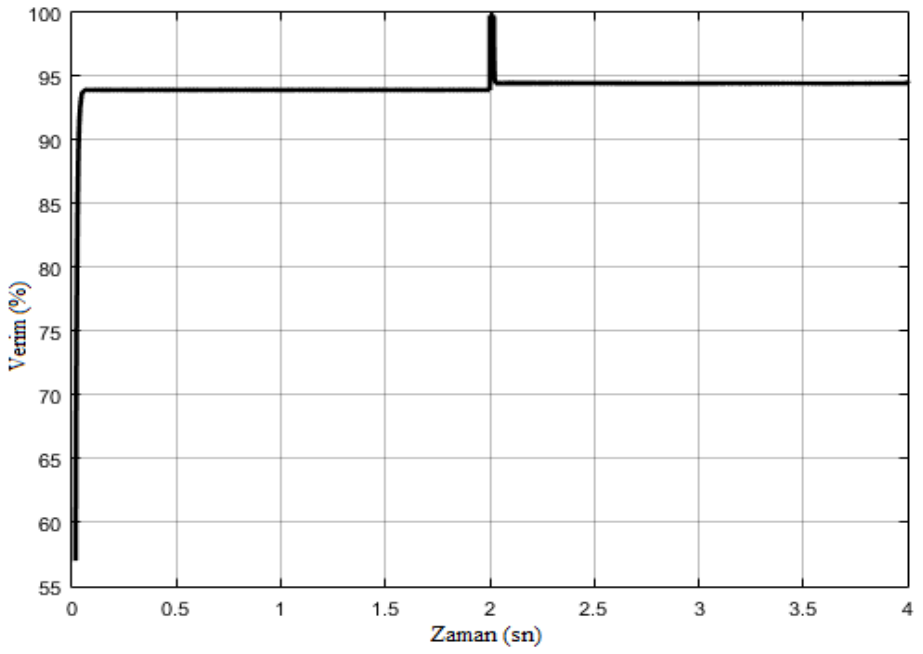

Şekil 15. Değiştir ve Gözlem algoritması için verim

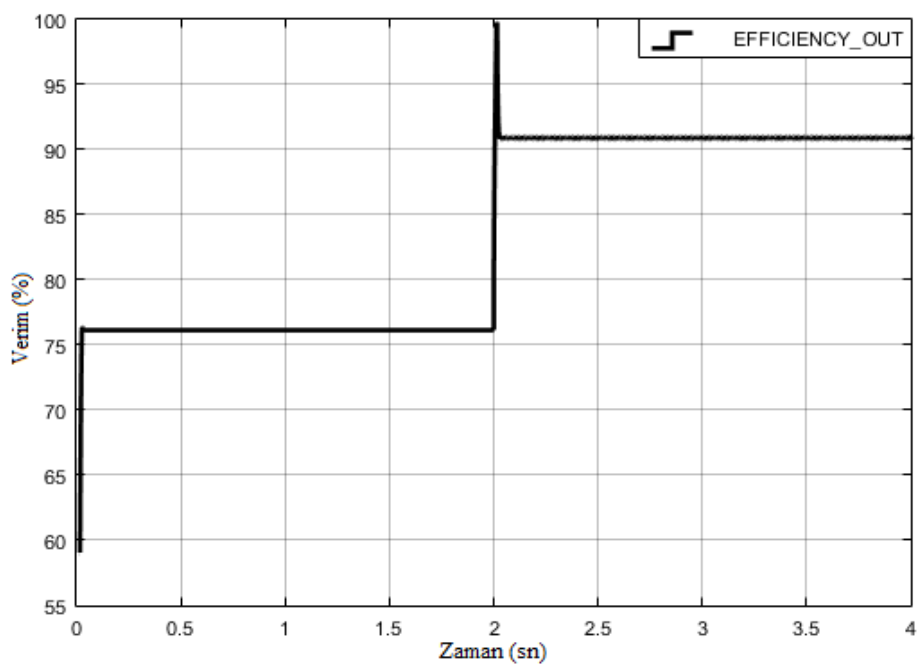

Şekil 16. Artan İletkenlik algoritması için verim

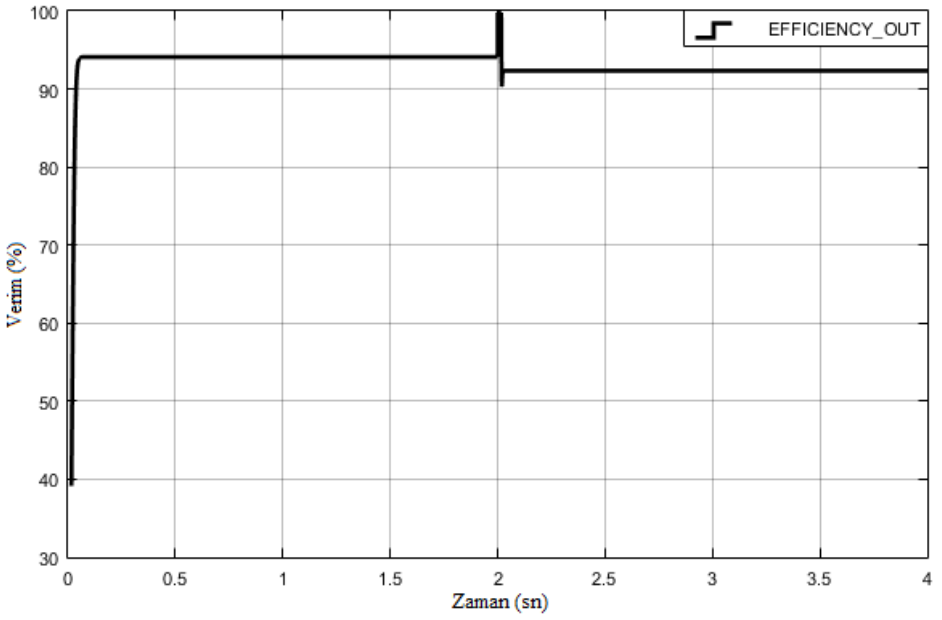

Şekil 17. Empedans Uyumluluğu algoritması için verim

Tablo 4. Her bir algoritmaya ait verim değerleri

\begin{tabular}{ccc}
\hline \hline & \multicolumn{2}{c}{ Zaman (sn) } \\
Algoritmalar & $0-2$ sn & 2-4 sn \\
& Verim (\%) & Verim (\%) \\
\hline \hline Değiştir ve Gözlemle & 93.93 & 94.46 \\
Artan İletkenlik & 76.14 & 90.93 \\
Empedans & 94.11 & 92.34 \\
Uyumluluğu & & \\
\hline
\end{tabular}

\subsection{Salınım Miktarı}

Tanımlanan her bir algoritma için, her bir çalışma koşulunda elde edilen maksimum güç noktasındaki salınım miktarlarının belirli kesit aralığındaki grafikleri Şekil 18, Şekil 19, Şekil 20'de verilmiştir. Elde edilen maksimum güç noktasındaki salınım miktarının tepeden tepeye sayısal değerleri ise Tablo 5'de verilmiştir.

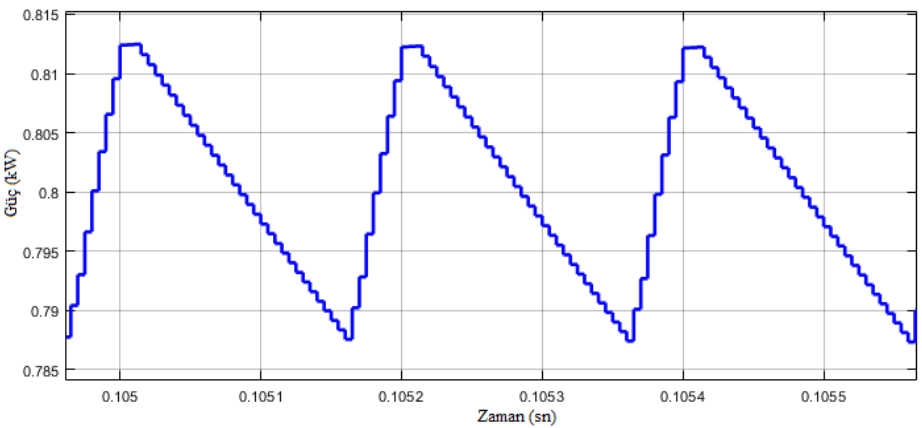

a) $t=0$. sn ve $t=2$.sn aralı̆̆ında maksimum güç noktasında salınım miktarı kesiti

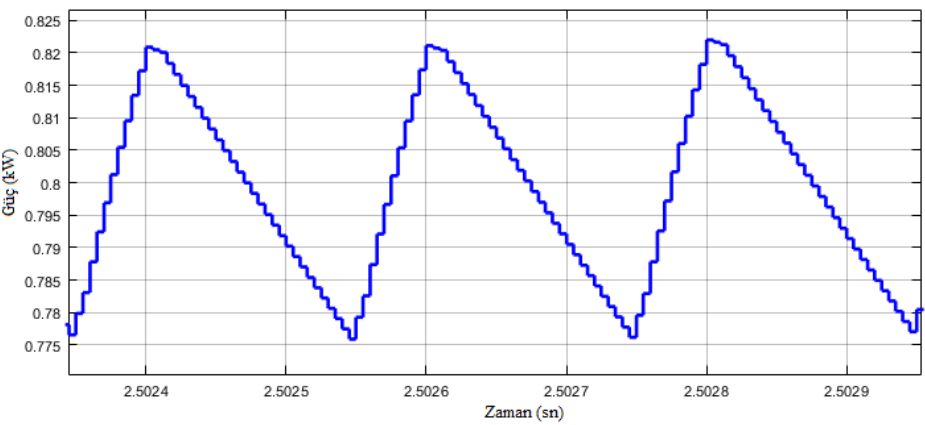

b) $t=2$. sn ve $t=4$.sn aralı̆̆ında maksimum güç noktasında salınım miktarı kesiti 
Şekil 18. Değiştir ve gözlemle algoritması için maksimum güç noktasında belirli kesiter aralığında salınım miktarı

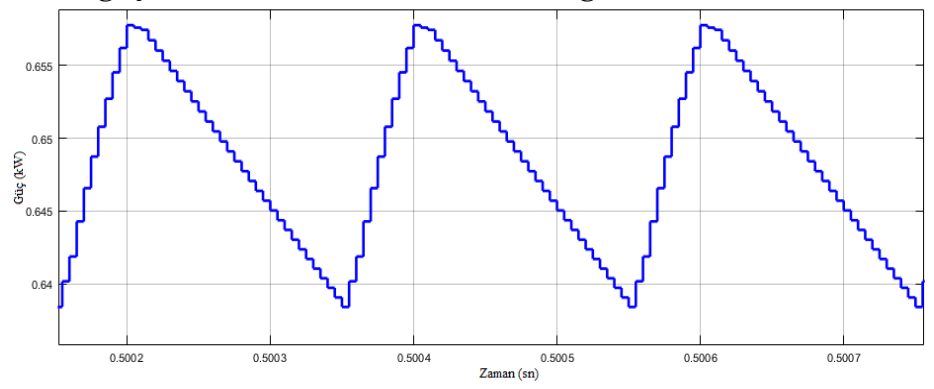

a) $t=0$. sn ve $t=2$.sn aralı̆̆ında maksimum güç noktasında salınım miktarı kesiti

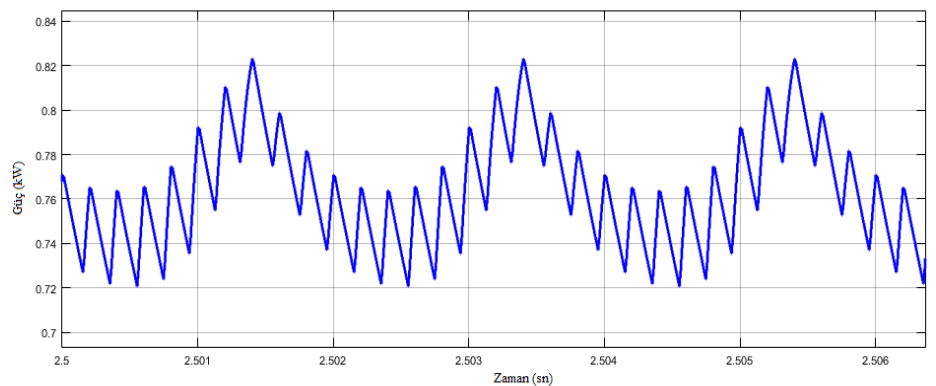

b) $t=2$. sn ve $t=4$.sn aralı̆̆ında maksimum güç noktasında salınım miktarı kesiti

Şekil 19. Artan iletkenlik algoritması için maksimum güç noktasında belirli kesiter aralı̆̆ında salınım miktarı

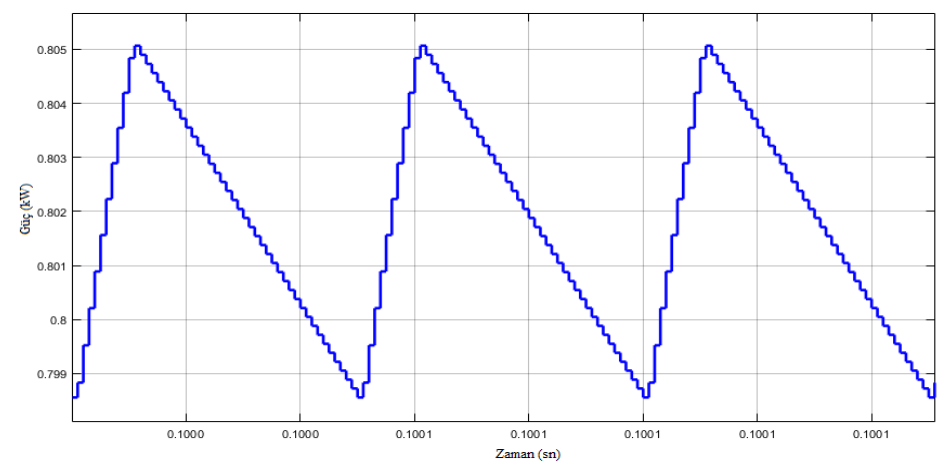

a) $t=0$. sn ve $t=2$. sn aralı̆̆ında maksimum güç noktasında salınım miktarl kesiti

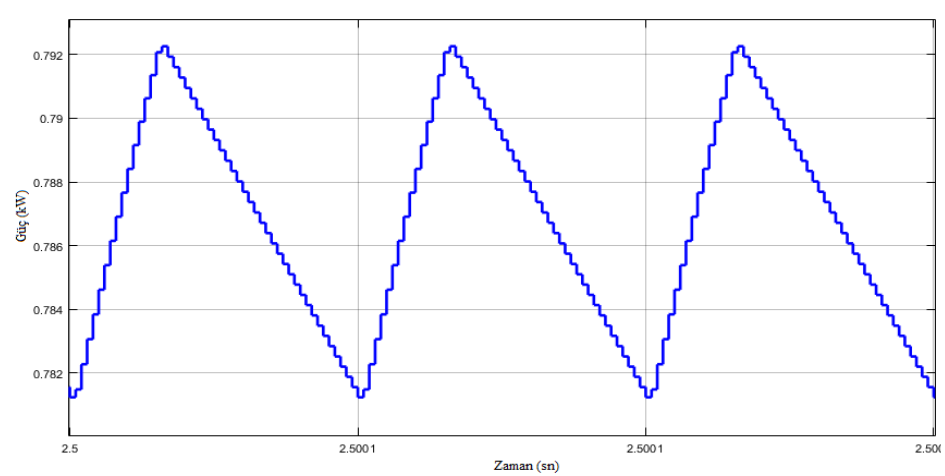

b) $t=2$. sn ve $t=4$.sn aralı̆̆ında maksimum güç noktasında salınım miktarı kesiti

Şekil 20. Empedans uyumluluğu algoritması için maksimum güç noktasında belirli kesiter aralığında salınım miktarı
Tablo 5. Her bir algoritmaya ait salınım miktarları

\begin{tabular}{ccc}
\hline \hline & \multicolumn{2}{c}{ Zaman (sn) } \\
Algoritmalar & $0-2$ sn & 2-4 sn \\
& Salınım $(\triangle \mathrm{W})$ & Salınım $(\triangle \mathrm{W})$ \\
\hline \hline Değiştir ve Gözlemle & 25 & 58 \\
Artan İletkenlik & 13.5 & 81 \\
Empedans & 5.9 & 11 \\
Uyumluluğu & & \\
\hline
\end{tabular}

\subsection{Yakınsama Süresi}

Tanımlanan her bir algoritma için, her bir çalışma durumunda sistemin maksimum güç noktasına ulaşması için gerekli olan yakınsama süreleri Şekil 21, Şekil 22, Şekil 23'de verilmiştir. Her bir çalışma durumu için belirlenen yakınsama sürelerinin sayısal değerleri ise Tablo 6'da verilmiştir.

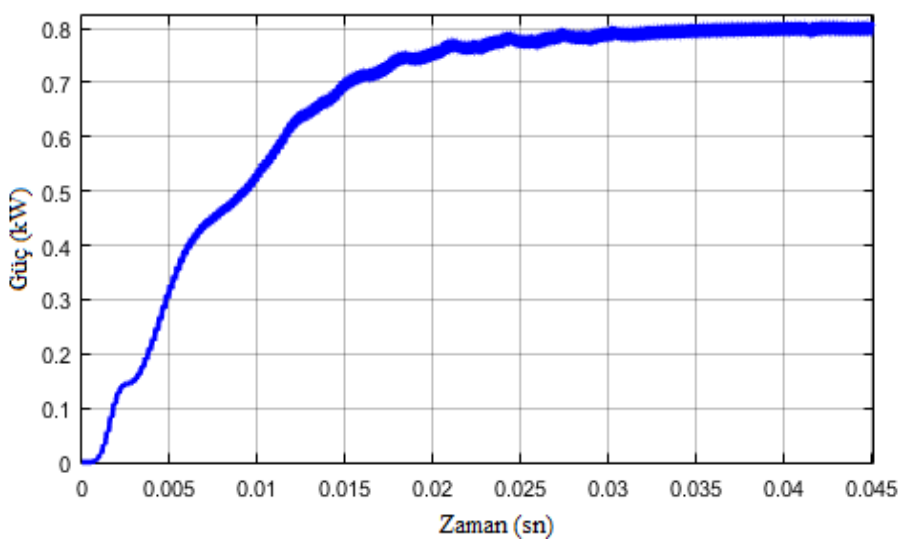

a) $t=0$. sn ve $t=2$. sn aralığında yakınsama süresi

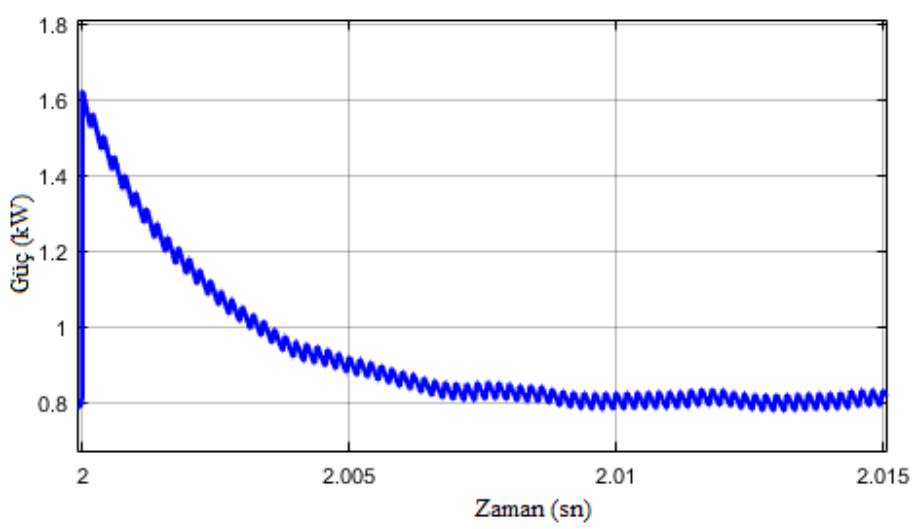

b) $t=2$. sn ve $t=4$.sn aralı̆̆ında yakınsama süresi

Şekil 21. Değiştir ve gözlemle algoritması için yakınsama süreleri 


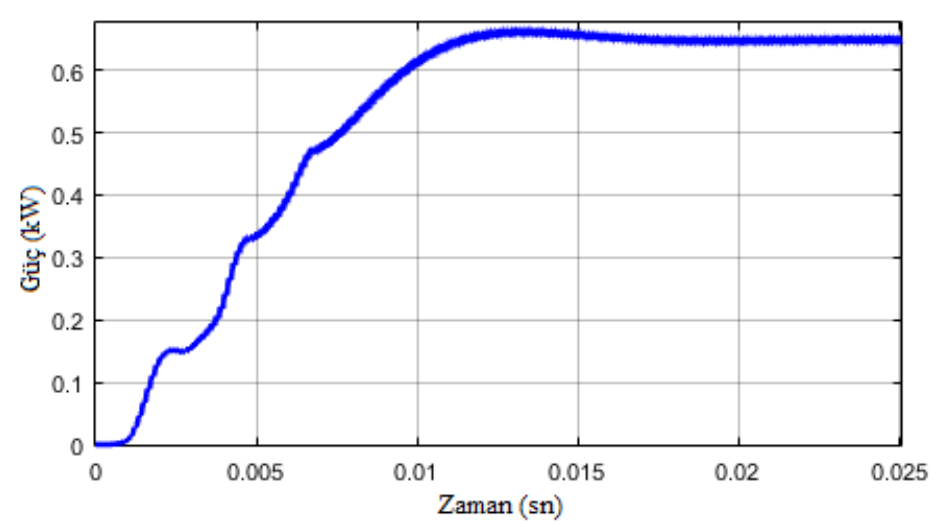

a) $\quad t=0$. sn ve $t=2$.sn aralığında yakınsama süresi

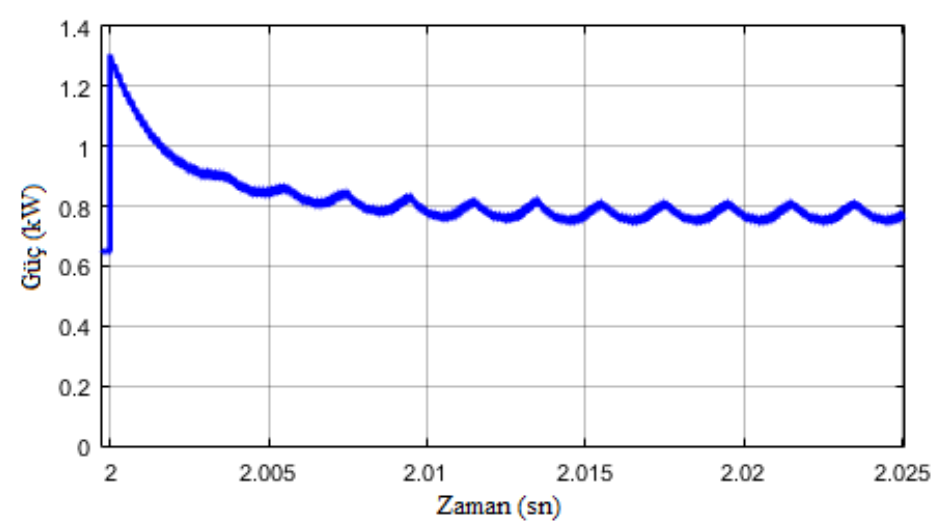

b) $t=2$. sn ve $t=4$.sn aralı̆̆ında yakınsama süresi

Şekil 22. Artan iletkenlik algoritması için yakınsama süreleri

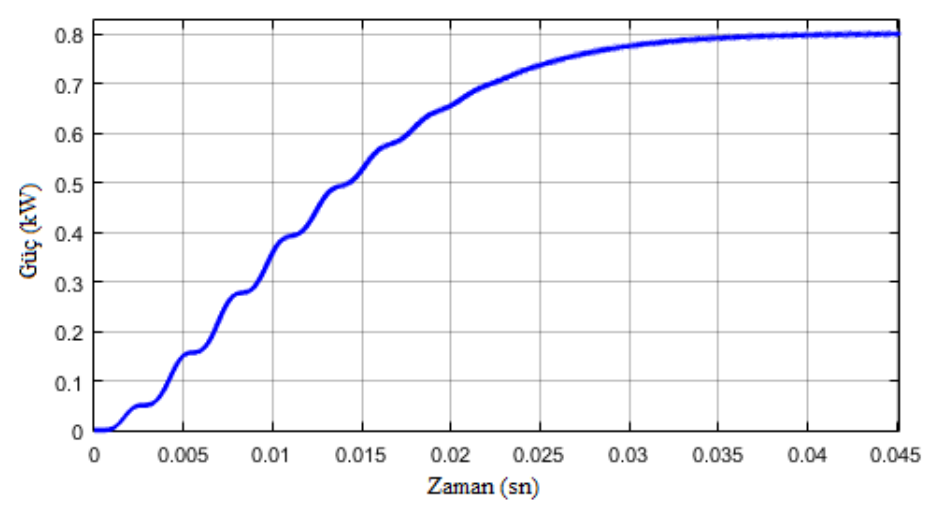

a) $\quad t=0$. sn ve $t=2$. sn aralığında yakınsama süres $i$

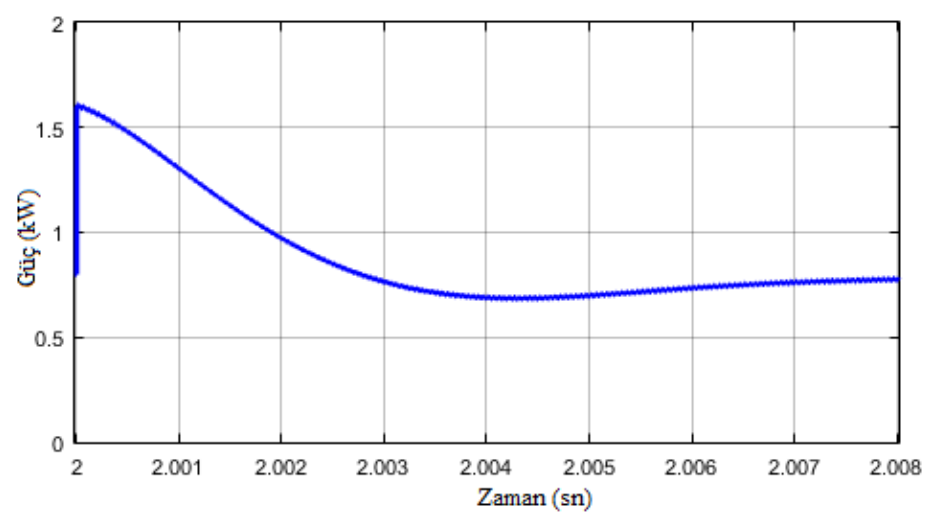

b) $t=2$. sn ve $t=4$.sn aralı̆̆ında yakınsama süresi

Şekil 23. Empedans uyumluluğu algoritması için yakınsama süreleri
Tablo 6. Her bir algoritma için yakınsama süreleri

\begin{tabular}{|c|c|c|}
\hline \multirow[b]{2}{*}{ Algoritmalar } & \multicolumn{2}{|c|}{ Zaman (sn) } \\
\hline & $\begin{array}{c}\text { 0-2 sn } \\
\text { Y.Süresi (ms) } \\
\end{array}$ & $\begin{array}{c}2-4 \mathrm{sn} \\
\text { Y.Süresi (ms) } \\
\end{array}$ \\
\hline Değiştir ve Gözlemle & 20 & 15 \\
\hline Artan İletkenlik & 25 & 25 \\
\hline Empedans & 45 & 8 \\
\hline Uyumluluğu & & \\
\hline
\end{tabular}

\section{Sonuçlar}

$\mathrm{Bu}$ çalışmada, MGNİ algoritmaları verim, maksimum güç noktasındaki salınım miktarı ve yakınsama süreleri açısından incelenmiş ve karşılaştırılmıştır. Bu algoritmalar arasında, ilk çalışma durumunda $(\mathrm{t}=0$.sn ve $\mathrm{t}=2$.sn aralığı) en yüksek verime ulaşan Empedans Uyumluluğu algoritmasıyken, ikinci çalışma aralığındaki ( $\mathrm{t}=2$.sn ve $\mathrm{t}=4 . \mathrm{sn}$ aralığ $)$ değişim durumunda en yüksek verime Değiştir ve Gözlemle algoritması ulaşmaktadır. Bunun sebebi, ilk durumda herhangi değişim yokken Empedans Uyumluluğu algoritması maksimum güç transferi yapabilmekte ve yük değişimi olmadığı için sisteme kolayca adapte olabilmektedir. İkinci çalışma durumunda sisteme paralel omik $100 \Omega$ 'luk yük ilave edildiğinde Empedans Uyumluluğu algoritması yük değişiminden olumsuz etkilenmekte ve Değiştir ve Gözlemle algoritmasına göre daha az verimle çalışmaktadır.

Maksimum güç noktasındaki salınım miktarı açısından değerlendirme yapıldığında, birinci çalışma aralığında $(\mathrm{t}=0 . \mathrm{sn}$ ve $\mathrm{t}=2$.sn aralığı) ve ikinci çalışma aralığında $(\mathrm{t}=2$.sn ve $\mathrm{t}=4$.sn aralığı) en az salınımı Empedans Uyumluluğu algoritması sağlamaktadır. Bunun sebebi, bu algoritmanın maksimum güç transferi ilkesine dayanıp maksimum güç noktasının yerini tespit ediyor olmasidir.

Yakınsama süresi açısından değerlendirme yapıldığında, birinci çalışma aralığında ( $\mathrm{t}=0 . \mathrm{sn}$ ve $\mathrm{t}=2 . \mathrm{sn}$ aralı $\breve{\mathrm{g}} 1)$ en ideal sistem Değiştir ve Gözlemle algoritmasıyken, ikinci çalışma aralığında $(t=2$.sn ve $t=4$.sn aralığ 1 ) en ideal sistem Empedans Uyumluluğu algoritmasıdır. $\mathrm{Bu}$ durumda Artan İletkenlik algoritması daha yavaş ilerlemektedir. Bunun sebebi, Artan iletkenlik algoritmasının hesap işlemlerinin, Değiştir Gözlemle ve Empedans Uyumluluğu algoritmalarına göre fazla zaman almasıdır. Aynı zamanda Artan İletkenik Algoritması ortam değişimlerine tepki süresi değiştir ve gözlemle algrotimasına göre daha uzundur.

Tüm algoritmalar için eşit şartlar sağlandığında ve sistemde herhangi bir yük değişimi olmadığında, Empedans Uyumluluğu algoritması daha yüksek verimlere ulaşılmasında daha iyi bir seçenek olacaktır. Eğer sistemde değişken omik yükler mevcutsa bu durumda daha yüksek verim değerlerine ulaşabildiği için Değiştir ve Gözlemle algoritmasının kullanılması daha uygun olacaktır. İleriki çalışmalarda değişken omik ve endüktif yük durumları ele alınabilir. 


\section{Kaynakça}

[1] Özbay, H., et al., 2016, "Farklı Eğim Açılarındaki Fotovoltaik Panellerin Elektriksel Ölçümlerinin Raspberry Pi ile İzlenmesi”, Düzce Üniversitesi Bilim ve Teknoloji Dergisi 4.2.

[2] Düz, H., 2016 , "Storing solar energy inside compressed air through a heat machine mechanism", Gazi University Journal of Science, 29.2, 245-251.

[3] Karafil, A., Ozbay, H. and Oncu, S., 2020, "Design and Analysis of Single Phase Grid Tied Inverter with PDM MPPT Controlled Converter", IEEE Transactions on Power Electronics $35.5,4756-4766$.

[4] Wenham, S. R., 2012, “Applied Photovoltaics", Routledge, London, 29-39.

[5] Leva S., Zaninelli D., and Contino R., 2007, "Integrated Renewable Sources for Supplying Remote Power Systems", WSEAS Transactions on Power Systems, 2,2, 41-48.

[6] Reisi A. R., Moradi M. H., Jamasb S., Classification and comparison of maximum power point tracking techniques for photovoltaic system: A review, Renewable and Sustainable Energy Reviews, 2013, 19, 433-443.

[7] Koizumi H., Kurokawa K., 2005, “A Novel Maximum Power Point Tracking Method for PV Module Integrated Converter", 36th IEEE Power Electronics Specialists Conference, (PESC'05), 2081-2086, USA.

[8] Basoglu ME., Cakir B., 2016, "Comparisons of MPPT performances of isolated and non-isolated DC-DC converters by using a new approach", Renewable \& Sustainable Energy Reviews, 60, 1100-1113.

[9] Ibnelouad A.; et al.; 2017, “A Comprehensive Comparison of the Classic and Intelligent Behavior MPPT Techniques for PV Systems", 14th International Multi-Conference on Systems, Signals \& Devices (SSD), Morocco.

[10] Kumar S.; Sahu HS.; Nayak SK.; 2019, "Estimation of MPP of a Double Diode Model PV Module From Explicit I-V Characteristic", IEEE Transactions on Industrial Electronics, Vol.66, Issue 9.pp.7032-4042.

[11] Heydari, M., Khoramikia, H., \& Fatemi, A., 2019, "Highvoltage gain SEPIC-based DC-DC converter without coupled inductor for PV systems", IET Power Electronics, 12.8, 21182127.

[12] Gupta PP., Kishore GI.; Tripathi RK., 2019, "Implementing High Gain DC-DC Converter with Switched Capacitor for PV System", Innovations in Power and Advanced Computing Technologies (i-PACT), India.

[13] Yadav I.; Maurya SK.; 2020, "Modelling and Analyzing of DC-DC Converter for Solar Pump Applicaitons", Int. Conference on Power Electronics \& IoT Applications in Renewable Energy and its Control, India.
[14] Kırcığlu O., Yıldız AB., 2015, "Fotovoltaik Panelin Tek Diyotlu Eşdeğer Devresine Ait Büyük Sinyal Analizi”, TMMOB Elektrik Mühendisleri Odası Enerji Verimliliği ve Kalitesi Sempozyumu.

[15] Nakir İ., 2007, "Fotovoltaik Güneş Panellerinde GTS ve MGTS Kullanarak Verimliliğin Arttırılması", Yüksek Lisans Tezi, Yıldız Teknik Üniversitesi, Fen Bilimleri Enstitüsü, İstanbul, 75 .

[16] Aslıhan K., 2010, "DA Çevirici Temelli Fotovoltaik Elektrik Üretim Sistemlerinin İncelenmesi ve Simülasyonu”, Yüksek Lisans Tezi, Yıldız Teknik Üniversitesi, Fen Bilimleri Enstitüsü, İstanbul,82.

[17] Tevfik K., 2013. "50W Led TV Uygulamaları İçin Güneş Enerjili Bir Güç Kaynağı Tasarımı ve Geliştirilmesi”, Yüksek Lisans Tezi, Hacettepe Üniversitesi, Ankara,121.

[18] Tekeshwar P.S., Dixit T.V., 2014, "Modelling and Analysis of Perturb \& Observe and Incremental Conductance MPPT Algorithm for PV Array Using Cuk Converter", IEEE Student's Conference on Electrical, Electronics and Computer Science.

[19] Rajiv R., Yatendra Y., Umashankar S. Vijayakumar D., 2013, "Modeling and Simulation of Incremental Conductance MPPT Algorithm Based Solar Photo Voltaic System using CUK Converter". 